\title{
The Existence of Malay Folklore in Medan
}

\author{
Ratih Baiduri ${ }^{1}$, Puspitawati ${ }^{2}$, Leyla Khairani ${ }^{3}$, Raudatul Khasanah ${ }^{4}$ \\ \{ratihbaiduri215@gmail.com ${ }^{1}$, puspita.ratmono@yahoo.com ${ }^{2}$, liakhairani@yahoo.com ${ }^{3}$ \} \\ Department of Anthropology Education, Universitas Negeri Medan, Indonesia 1, 2,3
}

\begin{abstract}
This study aims to determine the existence of Malay folklore in Medan. The type of research is qualitative research with a descriptive approach. The data collection techniques used were observation, in-depth interviews, and literature study. The theory used in this study is a cultural interpretation by Clifford Geertz. The selected informants consisted of Malay cultural figures, parents, teachers, children and storytellers. The results of this study found that Malay folklore has experienced degradation in the Malay cultural order, especially among children. The existence of this folklore is increasingly fading. This is due to the development of the era with global technology and culture that freely entered various regions in Indonesia through the digital world. The value of character education contained in the Malay folklore that religious values, social and moral or humanitarian. That is the need to revitalize Malay folklore by integrating the content of Malay folklore in the education curriculum with an attractive and fun learning model. Besides, it is necessary to reconstruct Malay folklore by packaging stories through interesting drama, film and video performances.
\end{abstract}

Keywords: existence, character education, Malay folklore

\section{Introduction}

Folklore is part of a collective culture that is spread and passed down from one generation to the next generation. Traditionally folklore has different versions from various ethnicities. According to Bascom, folklore is divided into three; they are myths, legends, and fables [1]. Folklore is a part of the culture that contains the values of character education following the philosophy of a region and culture. Folklores that developed in North Sumatra, have the value and meaning of character that can be used as a source of character building of children. However, due to technological advancements, globalization that is developing rapidly today presents a phenomenon of the rise of delinquency in children due to the bad influence of the development of internet media.

Many school children are addicted to playing gadgets, video games, accessing sites containing pornography, loss of social skills such as indifference (no empathy) and it also triggers the crime because of internet addiction such as cases of theft and violence against friends and parents. This phenomenon causes children to be no longer interested in reading, especially folklore. Besides, school curricula are more focused on pursuing curriculum targets by relying on cognitive knowledge rather than building noble morals causing folklore to cease to exist among students. Besides, local television shows (Indonesia) adopt more foreign cartoons rather than broadcast folklore from various regions and cultures of Indonesia. This bad behavior can be prevented through the inculcation of character at school through learning folklore, both taught at school and home. 
Folklore needs to be preserved by society by maintaining on teaching and playing folklore from generation to generation. In line with Indonesia's current educational goals, namely building the character of children of the nation by having good ethics and character. Education has an important role in human life because education is a basic need for humans. As stated in the 2013 National Education System Law, National education is an education based on the Pancasila and the 1945 Constitution of the Republic of Indonesia which is rooted in religious values, the national culture of Indonesia and responsive to the demands of changing eras.

The importance of schools to become an arena in introducing folklore to students have expressed by many experts namely Hamer [2]; Altman et al., [3]; Rosenberg [4]); Nusz [5], Bulger [6], but the efforts that are done by experts do not also make attention focused on making schools an arena learning folklore especially in Indonesia. It is ideal to shape the characteristics of children by introducing various folklore. Early age is a time of anxiety in child development. Therefore, to realize the goals of Indonesian education, it must be done since the early stage. At an early age to eight years, the human brains develop quickly or accept all that it sees and hears in its environment both positive and negative. If the child is in a positive environment, a better character can be formed and otherwise, if the child is around a negative environment, the character building is negative too. However, if the family instills positive things from an early age on children, then the bad environment will only have a slight effect.

Education in the family inherits cultural values obtained from generation to generation. Generally, parents educate children according to how the previous generation educated their children. The cultured family, school and community environment provides opportunities for character education to develop positive cultural noble values in the world of education. Therefore, it is necessary to develop local culture-based education. One of the ways is to introduce and familiarize children to hear and read folk tales in the area, such as folklore myths, legends, and fables.

Folklore is an effective media of providing value education to children. Because of the fun and non-compelling way of delivering, it makes children happy to accept them. Characters in folklore can set a good example for children. The nature or character of children tends to imitate and identify themselves with the characters they admire. Through folklore, children will easily understand the traits, figures, and good deeds and avoid bad deeds [7].

Malay folklores are referring to a series of knowledge, traditions, and restrictions on Malay culture that have been passed down in oral, written and symbolic forms. Malay folklores are fictional stories aimed at teaching media to children and helping parents in educating children with the traditional values of Malay. Various types of Malay folklore in the form of myths, legends, and fables in North Sumatra areas these followings : "Tuan Putri di Pucuk Kelupang", "Sayembara Bohong", "Sri Putri Cermin", "Putri Burung Kuau", "Selendang Delima", "Pak Belalang", "Si Kancil ", "Putri Hijau "," Bawang Putih Bawang Merah "," Si Tanggang "," Kisah Si Alamsyah" and "Batu Belah "(Batu Betangkup) and others. Of all the titles of the story certainly contains the meaning and value of good character education for children. This paper will only focus on several Malay folklore regarding on the fairy tales of "Tuan Putri di Pucuk Kelumpang", "Putri Hijau", "Pak Belalang" and "Si Kancil".

Folklore is one of the nation's cultural heritage, as well as, ancient objects, folk songs, and folk music. Folklore contains beliefs, outlook on life, ways of thinking, and cultural values. Many folklore or traditional stories are written in local languages. Furthermore, many of these folklores contain great ideas, noble thoughts, valuable soul experiences and so on [8]. 
However, it is unfortunate that more and more Malay folklores are disappearing of its influence because of the rare chance of people who preserve it. Though, folklore can build good character of children because each folk story contains values and morals in the formation of children's characters. Based on the background above, the writer is interested in conducting a study of the existence and value of Malay folklore in Medan.

This study aims to examine, find out the existence and value and meaning contained in Malay folklore in Medan. Geertz [9] states that meaning is public because the culture is public property. Geertz further said that cultural analysis is analyzing the meaning and describing explanatory conclusions from the analysis of meaning. Culture according to Geertz [9] is stated as a system of order and meaning, through which individuals define their world, express their feelings, and make their judgments. Geertz further stated that a pattern of historically transmitted meanings contained in these symbolic forms made humans able to communicate, establish and develop their knowledge of and attitude towards life. A symbolic tool aims to control behavior, extra somatic sources of information. Therefore culture is a system of symbols, the cultural process must be understood, translated, and interpreted through these symbols.

\section{Research method}

This type of research is qualitative research with a descriptive approach. Moleong [10] states that qualitative methods as a research procedure produce descriptive data in the form of written or oral words from people and observable behavior. Furthermore, Meleong states that qualitative research is the collection of data in a natural setting, using natural methods, and carried out by people or researchers who are naturally interested.

This research was conducted in Medan, North Sumatera, Indonesia. Researchers searched various places in Medan such as Balai Bahasa Sumatera Utara, North Sumatra Regional Library and Archives, Maimun Palace and Medan State University to explore the existence of Malay folklore literary works. The informants of this research are people who can provide information regarding the studies studied. The characteristics of selected informants include: (1) Malay cultural figures who are still active in writing Malay literature; (2) elementary school teachers; (3) parents who have children aged 7-12 years (4) storytellers in Medan. The data collection techniques by the authors in this study include (1) Observation; (2) In-depth interviews and (3) Documentation. Analysis of the data in this study is to do data reduction, display data and draw conclusions.

\section{Result and discussion}

"Tuan Putri di Pucuk Kelumpang" is Malay legend folklore originated from the Serdang Bedagai Regency which tells the life of a king in the Kelumpang country who needed a son who would be the successors to the royal throne. However, the fetus borne by the queen was female and she was struggling to get rid of it. Unfortunately, the queen gave birth to a princess. Knowing that the queen gave birth to a daughter who then would become a princess, she was very worried that the child would be killed by the king. Therefore, the queen finally took the princess to the forest and made a home for the princess's refuge in the Kelumpang tree. 
The "Putri Hijau" fairy tale is Malay legend folklore from the Deli Sultanate region in Medan, which tells the story of a daughter of Sultan Muhayat Syah, who was so beautiful and when the full moon shone her body emits a green color. He had two older brothers named Mambang Jazid and Mambang Khayali, who was able to transform into a cannon. Once the Sultan of Aceh wanted to propose to the princess and he then got rejected by Putri Hijau's two older brothers causing war broke out between the Sultan of Aceh and Deli Sultanate. Therefore the princess escaped into the Deli river from the palace and her brother turned into a cannon to fire at the enemy. However, in the middle of the journey, the princess was confronted by a dragon which was the embodiment of Mambang Jazid. Finally, the princess escaped and was not known to exist until now.

The legend folklore "Pak Belalang" tells the story of a lazy man who had a child named Belalang (Grasshopper) and because of that, he was called Pak Belalang (Mr. Grasshopper). Pak Belalang pretended to be an astrologer. Because of various events that occurred in a coincidental situation, Pak Belalang managed to answer questions that were quite difficult and eventually making him become a wealthy person. The fable folklore "Si Kancil" is a fable that tells the ingenuity and intelligence of a deer in saving himself and his friends.

Malay folklore in its present time has been undermined by the development of technology that is more attractive to the younger generation by playing gadgets rather than knowing Malay folklore. In general, folklore is almost non-existent in textbooks of school children and rarely appears in social life. Also, television media shows more often cartoon stories from abroad and our television rarely shows educational entertainment based on folklore.

Parents and schools are the most important foundation in preserving Malay folklore, and many are no longer familiar with Malay folklore. If traced its history, parents in the past were very active in telling folklore to their children. The government also has a very important role in supporting the preservation of Malay folklore by inviting active speakers to be able to uplift folklore stories to be better known to children. As stated by Rusdi, et al. [8]. Malay folklore is believed to have existed since the art of speech in oral traditions already existed, precisely before humans knew the written language. Folklore has always been a medium used by parents to convey messages to the next generation. Besides, folklore was once considered a precise method to instill the value of the character to the younger generation. Instilling moral values through folklore always draws attention because this method is interesting and far from being patronizing. The process of absorbing knowledge can be absorbed by the listener and stored in the memory of children without them knowing directly. The following illustrates the development of Malay folklore past and present.

Table 1. Malay folklore development (past and present)

\begin{tabular}{|c|c|c|}
\hline & Past & Present \\
\hline 1. & $\begin{array}{l}\text { Developing through oral } \\
\text { traditions from generation to generation }\end{array}$ & $\begin{array}{l}\text { The process of transformation was interrupted } \\
\text { because it was considered that those who } \\
\text { could tell stories were parents }\end{array}$ \\
\hline 2. & Folklore develops through performances & $\begin{array}{l}\text { People prefer to watch TV / Cinema rather } \\
\text { than traditional art shows }\end{array}$ \\
\hline 3. & Folklore is often used as a lullaby & Replaced by technological media \\
\hline 4. & Folklore uses local languages & Translated into good Indonesian \\
\hline 5. & Translated into good Indonesian & Rarely anyone can sing and hum \\
\hline
\end{tabular}

Based on the table above, we can see that the existence of folklore, especially Malay folklore, has experienced a decline (degradation) that has almost disappeared in the social 
fabric. The reason for the existence of Malay folklore is almost extinct at this time, Firstly, in the past, parents still had a lot of time to gather with their children. Thus they still had time to tell their children at least before they went to sleep. The power of speech art plays an active role in transforming stories from generation to generation. Now the culture is fading, disconnected due to busy parents. Children are allowed to read their storybooks, comics, illustrated stories or foreign novels. Parents now assume that the story is the task of the grandparents.

Secondly, the form of folklore was packaged in performing arts or drama performances. Various groups of artists create shows that uplift stories from folklore. Previously, this kind of performance was visited by many people and even became awaited show in Medan. The hardest story to show is about Putri Hijau. The mystical element that binds the story requires that the performers carry out the ceremony of asking permission first. The ceremony took the form of a procession of a sweeping yellow sassy into the Deli river. Performing arts set in folklore was once very on-demand, but slowly but surely later it lost its interest. Now, this staging is no longer interesting and is increasingly disappearing. The presence of television, cinema, and gadgets (internet) overcome traditional theatrics. In the end, this performing art disappeared from the culture of the Malay community in Medan.

Thirdly, folklore was often used as a bedtime media for children. Children were very enthusiastic about listening to folktales before bed and parents were also very happy to do it. However, at this time it has been replaced by technology. Parents prefer to give the gadget to their children as a medium for their children to sleep by watching videos on YouTube or playing games. Fourthly, other changes can be seen from the use of Malay in each story. Previously Malay was the language used in every story, but nowadays it is seldom able to speak Malay well and correctly. Fifthly, folklore was told while singing with Malay rhythm enhanced with the sweet voice of the narrators making every listener stunned in the folklore they sang. However, at this time it is rarely seen specifically poets of Malay folklore who can sing Malay folklore.

Value and meaning are two interrelated words, where the value contained in a matter that certainly has meaning in it. The value itself can be interpreted as a concept that shows things that are considered valuable in human life, namely about what is considered good, worthy, proper, right, important, beautiful, and desired by society in their lives. Conversely, things that are considered inappropriate, bad, wrong and not beautiful are considered as something priceless. While the meaning is defined as the meaning or message implicit in a matter, as well as the meaning contained in folklore.

Not only as reading material and entertainment, but folklore also has very good value and meaning to be applied in society's lives, especially for the children of the nation's next generation. Moreover, folklore has very good moral values to be applied to the young generation of Indonesia, given the phenomenon of the fading behavior of the younger generation which is now called the millennial generation due to the erosion of the digital era which is so free in expression and communicating without limits.

The values and meanings contained in the Malay folklore are: Firstly the Malay folklore entitled Legend of the Putri Hijau contained several values such as religious values, namely one is taught not to be hostile to each other and fight against each other. Because things Islam religious teachings, as implied in the story, teach to love and forgive each other among God's creatures. Not one of the world's religions teaches to clash with one another. Then in this story, there is also a moral value, namely that in making decisions one must not be rash, despair, and revenge against others. One is taught not to impose its will on others. War and attack each other is not a good solution for anyone to do. Towards siblings or relatives, one 
must protect and love one another. Second, the values contained in the Malay folklore titled Tuan Putri in Pucuk Kelumpang are religious and social. The story teaches that one must always be grateful to The Creator for all of his blessings. Then in this folklore, there are also moral messages and also good values such as the value of patience, loyalty and honesty. Where in the story one is taught to be obedient to parents and must always be patient with whatever happens to us and also one must be honest both in words and deeds. Furthermore, the social value taught in this story is to teach everybody not to discriminate between people in terms of gender, religion, love, race and so on. One is taught to be fair to anyone.

Third, the values contained in the Malay legend folklore, the story of Pak Belalang also contains moral values, namely honesty. Where in the story one is told that a lie is not good to continue to do. It only makes one's soul and mind uneasy. It's better, to be honest even though the reality is more painful than having to lie because after all, a lie will bring even greater disaster.

Finally, the values contained in fable folklore titled Si Kancil are moral and social. Its moral value is to teach someone to be wise and clever in dealing with various problems, must not be hasty in deciding on a matter. Must think smart about a problem to be free from problems. However, in the story of Si Kancil also taught one to use intelligence appropriately. This means that it cannot be used to harm others, such as cheating and stealing.

If related to the theory of interpretivism by Clifford Geertz who states that culture as a system of order and meaning, with these meanings and individuals, they define their world, express their feelings, and make their judgments. A pattern of historically transmitted meanings contained in symbolic forms, which through symbolic forms, humans communicate, establish, and develop their knowledge of and attitude towards life. This means that a culture that exists and is created in the fabric of society has an implied meaning within it and has a specific purpose. As is the case with Malay folklore which contains good meaning in each of its stories and can also affect the character of children. Folklore is the object or instrument that is appropriate as advice-giving media to children for their character building and set good examples for them as listeners. This is because folklore has good meanings and the stories have unique story characteristics and consequently, children prefer to listen for them. However, this meaning begins to shift along the times.

Folklore at present is something that is not considered important, ancient, mythical that does not influence the development of children's character. Unlike in the past, folklore had a very meaningful meaning for their enthusiast. Listening, and telling it to children and future generations and having books about folklore in the past has its pride. However, if folklore is packaged with new and interesting appearances, their influence may be significant for the development of children's character.

\section{Conclusion}

Malay folklore is a cultural heritage of the Malay community which should be passed down from one generation to the next. However, as the times change, Malay folklore experience degradation in society, especially among children. This is due to developments in the age of technology and foreign cultures that freely enter Indonesia through digital technologies and globalization.

The content of Malay folklore has a virtue value that is important for the building of children's character. The values and meanings contained in Malay folklore are (religious value) moral and social. We can see this from several Malay folklore stories about the Legend of Putri Hijau that have religious values of prohibition hostile to each other because they are 
forbidden by religion. The story of the Tuan Putri di Pucuk Kelumpang has social values that teach one not to discriminate against anybody in terms of gender, religion, ethnicity, race and so on. Furthermore, in the story of Pak Belalang and Si Kancil teach one to have honesty moral value.

Malay folklore has influences on the development of children's character. The influence of Malay folklore in the children's character building is that they have a polite attitude following the character of the nation, being devout worshiping, respecting and obeying parents and others, and children will have pride in their own culture and can preserve it to the next generation. However, today the existence of Malay folklore is considered outdated, ancient, and no longer interesting to be heard, read and exhibited anymore. Efforts are needed to revitalize Malay folklore by including the content of Malay folklore in the curriculum from early childhood education to tertiary institutions. Besides, this can be done by creating a new scenario by reconstructing Malay folklore using the technology of making film scripts, videos and performances that are popular among children so that they will be interested in Malay folklore. The effort that is no less important is to support the community of storytellers, artists who strive to return these Malay folk stories to attract the attention of the children of the nation's next generation.

Acknowledgments. Thank you to the Directorate of Research and Community Service (DRPM) of the Ministry of Research, Technology and Higher Education and LPPM Unimed which funded my 3rd-year research 2019 entitled "Local Wisdom-Based Character Education Model through Folk Stories in Early Childhood Education in Kindergarten Education in the City Medan ".

\section{References}

[1] Danandjaja, J.: Foklor Indonesia. Jakarta. Pustaka Utama Graffiti. pp. 2 (1984)

[2] Hamer, L.: Folklore in Schools and Multicultural Education: Toward Institutionalizing Noninstitutional Knowledge. The Journal of American Folklore. Vol. 113, no. 47, pp. 44-69 (2000).

[3] Altman, T. et al. Folklore and Education: A Selected Annotated Bibliography of Periodical Literature. Keystone Folklore. No. 22, pp. 53-85 (1978).

[4] Rosenberg, J. Folklife Study Guide Series. Texarkana: Texarkana Regional Arts and Humanities (1980).

[5] Nusz, N. Maritime Folklife in Lincoln Country: Student Magazine. Portland. Oregon Historical Society (1994).

[6] Bulger, P. Politics, Principles, and Principals. Southern Folklore., No. 48, pp.1320 (1991).

[7] Unsriana, L. Peranan Dongeng Dalam Pendidikan (Analisa Terhadap Lima Buah Dongeng Anak Jepang). http://www.digilib.ui.ac.id/opac/themes/libri2/detail.jsp?id=73562 (2003)

[8] Rusdi et al.,: Nilai-Nilai Budi Pekerti Yang Terkandung Dalam Cerita Rakyat Melayu Di Sumatera Utara. Banda Aceh. Balai Pelestarian Nilai Budaya Banda Aceh. pp. 2 (2013)

[9] Geertz, C. Tafsir Kebudayaan (Susanto, Budi Terj.). Yogyakarta. Kanisius. pp. 12 (1992)

[10] Meleong, Lexy K. Metode Penelitian Kualitatif. Bandung. Remaja Rosdakarya. pp.4 (2007) 